\title{
Corrigendum: Kynurenine is an endothelium-derived relaxing factor produced during inflammation
}

Yutang Wang, Hanzhong Liu, Gavin McKenzie, Paul K Witting, Johannes-Peter Stasch, Michael Hahn, Dechaboon Changsirivathanathamrong, Ben J Wu, Helen J Ball, Shane R Thomas, Vimal Kapoor, David S Celermajer, Andrew L Mellor, John F Keaney Jr, Nicholas H Hunt \& Roland Stocker

Nat. Med. 16, 279-285 (2010), published online 28 February 2010; corrected after print 6 May 2010

In the version of this article initially published, the symbol key in Figure $2 \mathrm{~g}$, h is incorrect. The correct symbol key is open circles for $I d o 1^{-1-}$ and filled circles for WT. The error has been corrected in the HTML and PDF versions of the article.

\section{Corrigendum: Obesity: stressing about unfolded proteins}

\section{Ronald C Wek \& Tracy G Anthony}

Nat. Med. 16, 374-376 (2010); published online 7 April 2010; corrected after print 6 May 2010

In the version of this News and Views initially published, the last name of one of the authors whose work was being discussed, Jonathon N. Winnay, was incorrectly spelled as 'Winney'. The error has been corrected in the HTML and PDF versions of the article.

\section{Erratum: Rebuilding Humpty Dumpty with a serotonin inhibitor}

Ego Seeman

Nat. Med. 16, 264-265 (2010); published online 5 March 2010; corrected after print 1 April 2010

In the version of this article initially published, several articles were eliminated from the reference list during layout, and several typographical errors were introduced. These errors have been corrected in the HTML and PDF versions of the article. 